\title{
Stereochemistry of the Electrochemical Hydrodimerization Reaction of Benzylidenemalononitrile. Dependence on Different Parameters
}

\author{
Steen U. Pedersen, Rita Grønbæk Hazell and Henning Lund* \\ Department of Organic Chemistry, University of Aarhus, DK-8000 Aarhus C, Denmark
}

\begin{abstract}
Pedersen, S. U., Hazell, R. G. and Lund, H., 1987. Stereochemistry of the Electrochemical Hydrodimerization Reaction of Benzylidenemalononitrile. Dependence on Different Parameters. - Acta Chem. Scand., Ser. B 41: 336-343.

Some benzylidenemalononitriles have been hydrodimerized in $\mathrm{N}, \mathrm{N}$-dimethylformamide (DMF) containing $1 \mathrm{M}$ acetic acid to cis- and trans-2-amino-4,5diaryl-2-cyclopentene 1,1,3-tricarbonitrile. The cis/trans ratio was found to depend on the nature and concentration of the supporting electrolyte and on the substrate concentration. It is proposed that the concentration influences the cis/ trans ratio by changing the mechanism from DIM 1 to DIM 2. The supporting electrolyte is suggested to influence the cis/trans ratio through ion-pair formation. The anion radicals of the benzylidenemalononitriles are so weakly basic that acetic acid does not protonate them; even trifluoroacetic acid in DMF does not protonate the anion radical completely.
\end{abstract}

Hydrodimerization is one of the most thoroughly studied cathodic reactions with respect to both mechanistic and synthetic aspects, ${ }^{1}$ primarily inspired by the synthetic importance of the hydrodimerization of acrylonitrile. The reduction of acrylonitrile has proved to be difficult to investigate mechanistically, and several model compounds have been employed to obtain information on the reaction. ${ }^{1}$

Benzylidenemalonitrile (1) and derivatives thereof with substituents in the phenyl ring have been used as model compounds in several laboratories; ${ }^{2-8}$ in one respect however, different results from two laboratories have been published. In 1975 it was found ${ }^{5,6}$ that the parent compound 1 was reduced in $N, N$-dimethylformamide (DMF)

$$
\mathrm{C}_{6} \mathrm{H}_{5} \mathrm{CH}=\mathrm{C}(\mathrm{CN})_{2}
$$

1

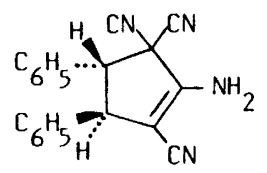

trans-2 containing $1 \mathrm{M}$ acetic acid to a mixture of cis- and trans-2-amino-4,5-diphenyl-2-cyclopentene-1,1,3tricarbonitrile (2) with an isomer ratio of approximately $1: 1$; later, however, it was reported ${ }^{7}$ that the reduction gave a nearly pure isomer, even when apparently the same conditions (DMF + $1 \mathrm{M}$ acetic acid) were used. The isomer was assumed to be the cis-2, but, as reported below, has been shown on the basis of an X-ray structure determination to be trans-2.

A preliminary investigation indicated a cis/ trans isomer ratio of 2:5, and further experiments, both electroanalytical and preparative, were therefore made to establish why so different results were obtained in three laboratories using apparently identical conditions.

\section{Results and discussion}

Electroanalytical investigation. p-Methylbenzylidenemalonitrile has been investigated by linear sweep voltammetry (LSV), ${ }^{2-8}$ convolution potential sweep voltammetry ${ }^{3}$ and chronopotentiometry in acetonitrile, ${ }^{4}$ as well as by LSV and derivative cyclic voltammetry (DCV) in acetonitrile and DMF containing acetic acid. ${ }^{8}$ Recently it has

\footnotetext{
*To whom correspondence should be addressed.
} 
Table 1. Dependence of half-peak potentials $E_{p / 2}$ of 1 $(1.0 \mathrm{mM})$ on $\left[\mathrm{LiClO}_{4}\right]$ in DMF. The slope $\mathrm{d} E_{\mathrm{p} / 2}$ $\left(\text { dlog }\left[\mathrm{LiClO}_{4}\right]\right)^{-1}$ is $18 \mathrm{mV}$ decade ${ }^{-1}$. Potentials vs. $\mathrm{Ag} / \mathrm{Agl}, 0.1 \mathrm{MI}^{-}$.

\begin{tabular}{ll}
\hline$\left[\mathrm{LiClO}_{4}\right] / \mathrm{M}$ & $E_{\mathrm{p} / 2} / \mathrm{mV}$ \\
\hline 0.01 & -638.5 \\
0.02 & -633.9 \\
0.03 & -630.5 \\
0.04 & -627.9 \\
0.05 & -626.0 \\
0.06 & -624.7 \\
0.08 & -622.6 \\
0.10 & -620.9 \\
\hline
\end{tabular}

been studied by LSV in benzonitrile. ${ }^{9}$ Here, 1 has been investigated by LSV and DCV in DMF containing acetic acid.

The dependence of $E_{\mathrm{p}}$ on the sweep rate $v\left[\mathrm{~d} E_{\mathrm{p}}\right.$ $\left.(\operatorname{dlog} v)^{-1}\right]$ was found for $[1]=8.0 \mathrm{mM}$ to be $-20.0 \mathrm{mV}$ (decade) $^{-1}$, which is close to that expected for a simple electron-transfer followed by a dimerization, DIM $1 ;{ }^{10}$ however, for $[1]=1.0$ $\mathrm{mM}, \mathrm{d} E_{\mathrm{p}}(\mathrm{d} \log v)^{-1}=-17.7 \mathrm{mV}(\text { decade })^{-1}$. The dependence of $E_{\mathrm{p}}$ on $[1]\left[\mathrm{d} E_{\mathrm{p}}(\mathrm{d} \log [1])^{-1}\right]$ was found to $19.0 \pm 0.5 \mathrm{mV}$ (decade) ${ }^{-1}$.

In Table 1, the dependence of $E_{\mathrm{p} / 2}$ on the concentration of lithium ion is given for 1 . The $E_{\mathrm{p} / 2}$ is shifted to less negative values, corresponding to an increase in the rate of the follow-up reaction. The $\mathrm{DCV}^{11,12}$ measurements give results in accordance with this (Table 2).

The reaction order with respect to 1 and acetic acid was investigated by DCV. The reaction order in HOAc was found to be 0 , whereas that in 1

Table 2. Dependence on $\left[\mathrm{LiClO}_{4}\right]$ of the reduction of $1(1.0 \mathrm{mM})$ measured by $\mathrm{DCV}$ in DMF/0.01 M TBABF $_{4}$. The subscript 0.4 refers to the constant ratio between the two derivative peak currents. $E_{\text {switch }}-E^{\circ}=300 \mathrm{mV}$. A reaction order in $\mathrm{LiClO}_{4}$ of 0.6 fits reasonably well to the data.

\begin{tabular}{lll}
\hline$\left[\mathrm{LiClO}_{4}\right]$ & $v_{0.4} / \mathrm{N} \mathrm{s}^{-1}$ & $v_{0.4} C_{\mathrm{i}}^{-0.6}$ \\
\hline 0.01 & 40.0 & 634 \\
0.03 & 73.9 & 605 \\
0.05 & 98.8 & 596 \\
0.07 & 134.9 & 665 \\
0.09 & 152.6 & 647 \\
\hline
\end{tabular}

Table 3. Reaction order analysis for 1 by DCV in $\mathrm{DMF} / 0.1 \mathrm{M} \mathrm{TBABF}_{4} ; T=20^{\circ} \mathrm{C}, E_{\text {switch }}-E^{\circ}=300 \mathrm{mV}$.

\begin{tabular}{llll}
\hline$[1] / \mathrm{mM}$ & {$[\mathrm{HOAC}] / \mathrm{mM}$} & $v_{0.5} / \mathrm{Vs}^{-1}$ & $v_{0.5}[1]^{-1} / \mathrm{Vs}^{-1} \mathrm{mM}^{-1}$ \\
\hline 0.5 & 20.0 & 80.3 & 160.6 \\
1.0 & 20.0 & 142 & 142.2 \\
2.0 & 20.0 & 184 & 92.0 \\
4.0 & 20.0 & 309 & 77.4 \\
8.0 & 20.0 & 359 & 44.8 \\
2.0 & 10.0 & 236 & \\
2.0 & 20.0 & 203 & \\
2.0 & 40.0 & 200 & \\
2.0 & 60.0 & 213 & \\
2.0 & 100.0 & 212 & \\
\hline
\end{tabular}

decreased with increasing concentration from close to 2 to close to 1 , with an average of 1.5 (Table 3). This means that at higher substrate concentration the reaction becomes slower than expected.

The LSV and DCV results thus point to a reaction, the first approximation of which is an electron-transfer followed by a dimerization of the anion radical (DIM 1); however, the influence of the substrate concentration and supporting electrolyte concentration indicates that the reaction is more complicated. This is in accordance with previously published results. ${ }^{8}$

Preparative reductions. In view of the different stereochemical results published for this reaction, the number of parameters, such as $\left[\mathrm{H}_{2} \mathrm{O}\right]$, [HOAc], the electrode material and the temperature, was systematically varied without having any effect on the stereochemistry. The conditions used in our laboratory [substrate concentration $40 \mathrm{mM}$, supporting electrolyte tetrabutylammonium iodide $(0.1 \mathrm{M})$ ] always gave a cis/trans ratio of approximately 2:5, with small variations, but never anything approaching a ratio of $1: 1^{5}$ or $1: 20 .^{7}$

However, varying the concentration of $\mathbf{1}$, while keeping other parameters, including $\left[\mathrm{Bu}_{4} \mathrm{NI}\right]$, unchanged, produced a significant effect on the cis/ trans ratio (Table 4). Also, varying the nature and concentration of the supporting elecrolyte, while keeping the other parameters, including the substrate concentration, constant, changed the cis/ trans ratio (Table 5). Tables 4 and 5 show that at high substrate:supporting electrolyte ratio more trans isomer is produced than at a low ratio. 
Table 4. Dependence of the cis/trans ratio of 2 on [1] in the hydrodimerization of 1 in DMF/0.1 $\mathrm{M} \mathrm{TBABF}_{4}$ containing $1 \mathrm{M}$ acetic acid. The cis/trans ratio was measured by HPLC.

\begin{tabular}{rl}
\hline$[1] / \mathrm{mM}$ & cis-2/trans-2 \\
\hline 1.0 & 1.01 \\
4.0 & 0.87 \\
8.0 & 0.77 \\
16.0 & 0.71 \\
24.0 & 0.46 \\
40.0 & 0.37 \\
60.0 & 0.36 \\
120.0 & 0.32 \\
\hline
\end{tabular}

The results from three constant-current reductions are presented in Table 6 . We varied the substrate concentration and the current density. The second row in each block in Table 6 shows the measured cis/trans ratio and the third row shows the cis/trans ratio produced in the interval between two subsequent measurements. Varying the substrate concentration strongly affects the isomer ratio, whereas varying the current density (anion radical concentration) only slightly affects it. This is in accordance with the results obtained by Delaunay et al. ${ }^{7}$ where high substrate concentrations were used in the preparative reductions.

Indirect electrolysis of 1 was carried out using methylviologen dichloride $\left(1,1^{\prime}\right.$-dimethyl-4,4'-bipyridinium dichloride) as mediator. The latter was reduced at the second reduction wave, which was reversible in cyclic voltammetry even in the presence of large concentrations of acetic acid.
Table 5. Dependence of the cis/trans ratio of 2 on the concentration and type of supporting electrolyte in the hydrodimerization of $1(40 \mathrm{mM})$ in DMF containing $1 \mathrm{M}$ acetic acid. The cis/trans ratio was measured by HPLC.

\begin{tabular}{lll}
\hline $\begin{array}{l}\text { Supporting } \\
\text { electrolyte }\end{array}$ & Conc./M & cis-2/trans-2 \\
\hline TBAI & 0.01 & 0.28 \\
$\mathrm{TBAI}$ & 0.10 & 0.37 \\
$\mathrm{CaCl}$ & 0.10 & 0.42 \\
$\mathrm{NaBF}_{4}$ & 0.10 & 0.54 \\
$\mathrm{LiClO}_{4}$ & 0.10 & 0.63 \\
\hline
\end{tabular}

This reaction resulted in formation of only trans-2 (>95\%).

Results from reduction of similar activated olefins $^{2-8}$ have suggested that the dimerization/cyclization is initiated by coupling of the two benzylic carbon atoms, and this being the case, the stereochemistry of the cyclic product is established during this coupling.

We assume that the DIM 1 mechanism, perhaps somewhat modified, is operating under the conditions prevailing for CV, LSV and DCV, partly because the LSV data and some of the DCV data support this mechanism and partly because other similar olefins have been shown to follow the DIM 1 mechanism, ${ }^{10}$ although modifications of the mechanism have been proposed. ${ }^{8}$ The anion radicals of 1 are assumed to undergo fast and stereochemically indiscriminate coupling at the benzyl carbons, which would result in

Table 6. Changes in the cis-2/trans-2 ratio during hydrodimerization of 1 in $\mathrm{DMF} / 0.1 \mathrm{M} \mathrm{TBABF}_{4}$ containing 1.2 $\mathrm{M}$ acetic acid, using constant current. Expt. I, [1] $=20 \mathrm{mM} . i_{1}=0.02 \mathrm{~A} ; \mathrm{II},[1]=40 \mathrm{mM}, i_{\|}=0.02 \mathrm{~A} ; \mathrm{III},[1]=40$ $\mathrm{mM}, i_{\mathrm{III}}=0.04 \mathrm{~A}$. cis/trans is the isomer ratio of 2 in the catholyte at the $n$-value indicated; $\Delta$ cis/trans is the isomer ratio of 2 produced between two successive $n$-values.

\begin{tabular}{|c|c|c|c|c|c|c|c|c|c|}
\hline 1 & $\begin{array}{l}n / F \text { mol }^{-1} \\
\text { cis/trans } \\
\Delta \text { cis/trans }\end{array}$ & $\begin{array}{l}0.145 \\
0.225 \\
0.225\end{array}$ & $\begin{array}{l}0.21 \\
0.239 \\
0.271\end{array}$ & $\begin{array}{l}0.28 \\
0.263 \\
0.342\end{array}$ & $\begin{array}{l}0.40 \\
0.283 \\
0.335\end{array}$ & $\begin{array}{l}0.47 \\
0.296 \\
0.375\end{array}$ & $\begin{array}{l}0.74 \\
0.393 \\
0.570\end{array}$ & $\begin{array}{l}0.84 \\
0.425 \\
0.800\end{array}$ & $\begin{array}{l}1.01 \\
0.471\end{array}$ \\
\hline II & $\begin{array}{l}n / F \text { mol}^{-1} \\
\text { cis/trans } \\
\Delta \text { cis/trans }\end{array}$ & $\begin{array}{l}0.10_{3} \\
0.080 \\
0.080\end{array}$ & $\begin{array}{l}0.14 \\
0.109 \\
0.197\end{array}$ & $\begin{array}{l}0.17_{5} \\
0.122 \\
0.182\end{array}$ & $\begin{array}{l}0.26 \\
0.149 \\
0.209\end{array}$ & $\begin{array}{l}0.35 \\
0.163 \\
0.207\end{array}$ & $\begin{array}{l}0.44 \\
0.178 \\
0.237\end{array}$ & $\begin{array}{l}0.54 \\
0.187 \\
0.290\end{array}$ & $\begin{array}{l}0.69 \\
0.220 \\
0.310\end{array}$ \\
\hline III & $\begin{array}{l}n / F \text { mol }^{-1} \\
\text { cis/trans } \\
\Delta \text { cis/trans }\end{array}$ & $\begin{array}{l}0.07 \\
0.102 \\
0.102\end{array}$ & $\begin{array}{l}0.10_{3} \\
0.123 \\
0.167\end{array}$ & $\begin{array}{l}0.14 \\
0.140 \\
0.189\end{array}$ & $\begin{array}{l}0.28 \\
0.148 \\
0.179\end{array}$ & $\begin{array}{l}0.22 \\
0.155 \\
0.189\end{array}$ & $\begin{array}{l}0.32 \\
0.173 \\
0.214\end{array}$ & $\begin{array}{l}0.44 \\
0.192 \\
0.244\end{array}$ & $\begin{array}{l}0.52 \\
0.206 \\
0.290\end{array}$ \\
\hline
\end{tabular}


equal amounts of the cis and trans isomers of 2 as found in some cases. ${ }^{5}$

At higher substrate concentration, outside the range of both the LSV and DCV techniques, the DIM 2 mechanism is suggested to compete successfully with the DIM 1 mechanism. One reason for this is that the current in preparative reductions at high substrate concentration usually is lower than the limiting current, as a result of the power limitations of the potentiostat; at the electrode surface there is thus a high concentration of substrate together with a certain concentration of anion radical. Another factor favouring the DIM 2 mechanism is that there is no charge repulsion in the coupling between an anion radical and the substrate. The reason why this mechanism leads purely to the trans isomer could be that during the coupling, the negative charge is shared to some degree between an anion radical and a substrate molecule, possibly through rapid electron exchange between the two species, thus forming a kind of "electron-exchange complex".

At some stage the coupling in the DIM 2 case has to be reversible, possibly in the proposed "electron-exchange complex", so that pure trans-2 can be formed.
There is ample precedent for an influence of the supporting electrolyte on the product formation in hydrodimerizations. ${ }^{5,16}$ The cathodic reduction of $\alpha$-phenylcinnamonitrile in wet DMF gives a mixture of cyclic and linear hydrodimers; $\mathrm{Et}_{4} \mathrm{~N}^{+}$promotes cyclization, whereas. $\mathrm{Li}^{+}$promotes formation of the linear dimer. Although the cathodic reduction of 1 always forms the cyclic product, no matter which cation the supporting electrolyte contains, the cations can play a role in the stereochemistry of the dimerization. When small and "hard" cations like $\mathrm{Li}^{+}$are available, they will tend to associate with the negative charge on the nitrile groups and hereby cancel some of the charge repulsion in the DIM 1 mechanism. This mechanism is then favoured compared to the DIM 2 mechanism and the dimerization becomes faster and sterically undiscriminating.

The competition between the DIM 1 and DIM 2 mechanisms can explain the observed trend in isomer ratio as a function of [1]. At low [1], when the electrolysis is performed at the potential of the limiting current, [1] is very low, and only the fast and random coupling of the anion radicals takes place, forming equal amounts of the two

$$
\begin{aligned}
& \mathbf{1}+\mathrm{e} \rightleftharpoons 1^{-} \\
& \mathbf{1}^{-}+\mathbf{1}^{-} \stackrel{k_{1}}{\rightarrow}(\mathbf{1}-\mathbf{1})^{2-} \rightarrow \rightarrow \text { cis-2/trans-2 } \sim 1 / 1 \\
& \mathbf{1}^{-}+\mathbf{1} \underset{k_{-2}}{\stackrel{k_{2}}{\rightleftharpoons}}(1-1)_{d, l}^{--}+(1-1)_{\text {meso }}^{--} \quad K_{2}=k_{2} / k_{-2} \\
& (\mathbf{1}-\mathbf{1})_{d, \bar{l}}^{\stackrel{-}{(}} \stackrel{k_{3}}{\rightarrow}\left(\cdot 1-1^{-}\right)_{d, l} \rightarrow \rightarrow \text { trans-2 } \\
& (1-1)_{\text {meso }}^{--} \stackrel{k_{4}}{\rightarrow}\left(\cdot 1-1^{-}\right)_{\text {meso }} \rightarrow \rightarrow \text { cis-2 }
\end{aligned}
$$

Rate of product formation $=k_{1}\left[\mathbf{1}^{-}\right]^{2}+k_{3} K_{2}\left[\mathbf{1}^{-}\right][\mathbf{1}]+k_{4} K_{2}\left[\mathbf{1}^{-}\right][\mathbf{1}]$

Scheme 1. 
isomers of 1. At higher [1], the potential corresponds to the foot of the wave, DIM 2 is favoured, and we obtain more and more of the trans isomer at the expense of the cis isomer. In Scheme 1 the proposed mechanism is shown. Application of the steady-state approximation for the (1-1) ${ }^{-}$complex yields the trans-2:cis-2 relation of eqn. (6).

In indirect electrolysis, the reduction of 1 will occur at some distance from the electrode where $\left[1^{-}\right]$is quite low and [1] high. Under these circumstances one would expect the DIM 2 mechanism to be favoured, and in accordance with this we observed the formation of pure trans-2. This result, together with the independence of the cis/ trans ratio on the electrode material, makes it unlikely that adsorption plays a decisive role in determining the stereochemistry of the coupling.

The dimerization of $\mathbf{1}$ is not affected by acetic acid; the anion radical is thus only weakly basic. It is unexpected that the resulting dianion or the monoprotonated dimer undergo a ring-closure rather than being protonated to give the linear dimer. However, if it is assumed that $\mathrm{p} K_{\mathrm{a}}$-values for acids in DMSO and DMF run parallel, and that $\mathrm{p} K_{\mathrm{a}}$ for the linear dimer of 1, 2,3-diphenyl1,1,4,4-butanetetracarbonitrile, is close to that for malononitrile $\left(\mathrm{p} K_{\mathrm{a}}=11.1\right.$ in $\left.\mathrm{DMSO}^{13}\right)$, then acetic acid $\left(\mathrm{p} K_{\mathrm{a}}=12.6\right.$ in $\left.\mathrm{DMSO}^{14}\right)$ is not strong enough to protonate the dianion formed in the dimerization. This does not exclude the possibillity that the species undergoing the ring-closure is the monoprotonated dimer.

We have also obtained experimental results which do not seem to be in accordance with the proposed mechanism. The constant-current electrolysis showed that the isomer ratio was only slightly dependent on $\left.\mathbf{1}^{-}\right]$(current density). This should not be the case according to eqn. (6). If the DIM 1 mechanism is so fast that the isomers are formed randomly, then it required a high substrate:anion radical ratio for the DIM 2 mechanism to compete. The DIM 2 mechanism is believed to be slower and more sensitive to conformational energies.

A surprisingly small activation energy (1.6 to $5.3 \mathrm{kcal} \mathrm{mol}^{-1}$ ) was found by Parker et al. ${ }^{8}$ for the reduction of $p$-methylbenzylidenemalononitrile; this does not seem to be in accordance with a simple mechanism. Parker ${ }^{8}$ has suggested a pre-equilibrium complexation.

Structure of one of the isomers of 2-amino-4,5diphenyl-2-cyclopentene-1,1,3-tricarbonitrile.

Crystals of 2-amino-4,5-diphenyl-2-cyclopentene1,1,3-tricarbonitrile · diethyl ether, $\mathrm{C}_{20} \mathrm{H}_{14} \mathrm{~N}_{4}$. $\mathrm{C}_{4} \mathrm{H}_{10} \mathrm{O}$, are monoclinic, $P 2_{1} / c$ (No. 14), with $a=$ $10.638(3), b=12.219(3), c=18.990(3) \AA, \beta=$

Fig. 1. ORTEP drawing showing the numbering used and the distances in the central part of the molecule.

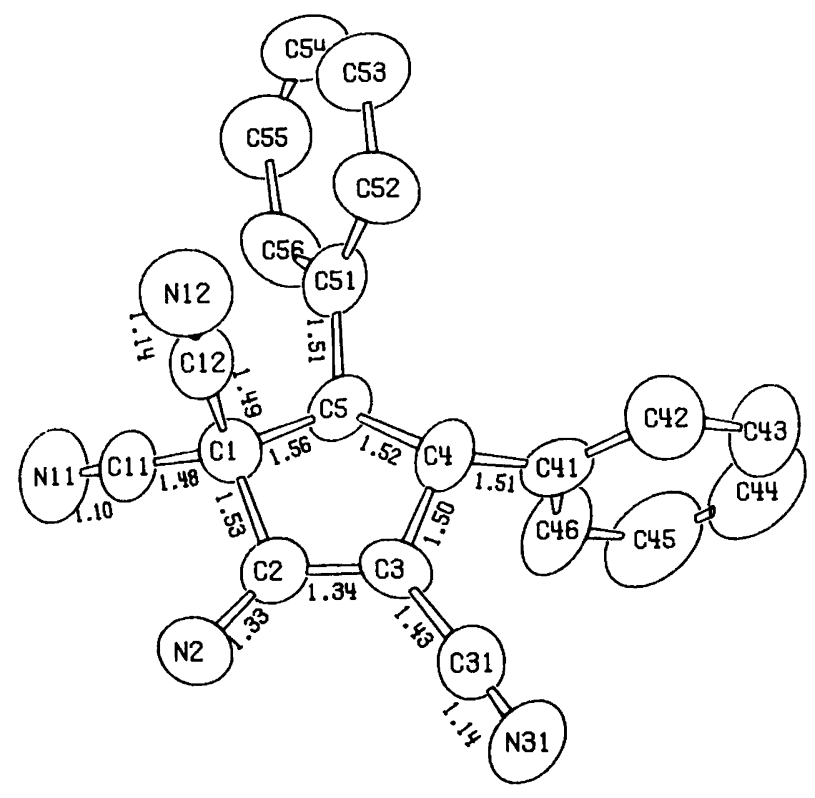


$112.38(1)^{\circ}, Z=4, V=2282.4 \AA^{3}, D_{\mathrm{x}}=1.119 \mathrm{~g}$ $\mathrm{cm}^{-3}, \mu(\mathrm{MoK} \alpha)=0.066 \mathrm{~mm}^{-1}$. The X-ray structure analysis shows that the isomer produced in indirect electrolysis has the trans configuration as shown in Fig. 1, which also shows the bond lengths in the central part of the molecule. The phenyl groups are in equatorial positions and form angles of 90 and $65^{\circ}$ with the central 5-ring. The ethylene double bond is somewhat delocalized onto the amino nitrogen, which has an $s p^{2}$ hybridization. One hydrogen of the amino group forms a hydrogen bond $(\mathrm{N}-\mathrm{H} \cdots \mathrm{O}=2.94 \AA)$ to the ether oxygen.

\section{Experimental}

The electroanalytical experiments were all performed at the Department of Chemistry, Univer- sity of Copenhagen. The instrumentation, electrodes, cells, data handling procedures, and the solvent and supporting electrolyte were the same as described earlier. ${ }^{18}$

Reagents. For preparative reduction, analytical grades of tetrabutylammonium iodide (TBAI) (Bergchemie, BRD) and DMF (Fluka AG, Switzerland) were used. The DMF was stored over molecular sieves. $\mathrm{LiClO}_{4}$ and $\mathrm{NaBF}_{4}$ (purum) were also from Fluka, whereas $\mathrm{CaCl}_{2}$ and the acetic acid (zur Analyse) were from Merck. Methylviologen dichloride was obtained from BDH Chemicals Ltd., England.

The benzylidenemalononitrile was prepared by the reaction of equimolar amounts of benzaldehyde and malononitrile in absolute ethanol catalyzed by a small amount of piperidine. ${ }^{17}$ The

Table 7. Final fractional coordinates $\left(\times 10^{4}\right)$ of the non-hydrogen atoms for trans-2, equivalent isotropic thermal parameters $\left(\AA^{2} \cdot 10^{-3}\right)$ and the distances $d(\AA)$ from the best plane through the central 5-ring.

\begin{tabular}{|c|c|c|c|c|c|}
\hline Atom & $x$ & $y$ & $z$ & $u_{\text {iso }}$ & $d$ \\
\hline C1 & $5567(11)$ & $1205(10)$ & $2710(6)$ & $56(9)$ & 0.18 \\
\hline $\mathrm{C} 2$ & $5433(12)$ & $893(7)$ & $3462(6)$ & $62(10)$ & -0.08 \\
\hline C3 & $4143(12)$ & $584(7)$ & $3306(6)$ & $55(9)$ & -0.05 \\
\hline C4 & $3260(13)$ & $693(8)$ & $2475(7)$ & $64(9)$ & 0.16 \\
\hline C5 & $4070(10)$ & $1465(10)$ & $2182(6)$ & $63(10)$ & -0.21 \\
\hline $\mathrm{C} 11$ & $6455(11)$ & 2167(11) & $2783(6)$ & $66(10)$ & -0.65 \\
\hline N11 & $7108(9)$ & $2886(8)$ & $2827(6)$ & 104(9) & -1.26 \\
\hline $\mathrm{C} 12$ & $6075(10)$ & $235(10)$ & $2420(6)$ & $63(10)$ & 1.63 \\
\hline N12 & $6396(9)$ & $-540(8)$ & $2197(5)$ & $93(8)$ & 2.76 \\
\hline N2 & $6528(9)$ & $857(6)$ & $4101(5)$ & $76(7)$ & -0.16 \\
\hline C31 & $3685(9)$ & $120(8)$ & $3857(7)$ & $66(8)$ & -0.10 \\
\hline M31 & $3388(8)$ & $-247(7)$ & $4322(5)$ & $93(7)$ & -0.14 \\
\hline C41 & $1797(14)$ & $1017(15)$ & $2279(6)$ & $66(12)$ & -0.53 \\
\hline $\mathrm{C} 42$ & $722(22)$ & $321(9)$ & $1926(7)$ & $81(10)$ & \\
\hline $\mathrm{C} 43$ & $-613(20)$ & $622(18)$ & $1759(7)$ & $115(13)$ & \\
\hline C44 & $-919(17)$ & $1639(22)$ & 1928(9) & $135(19)$ & \\
\hline V45 & 137(27) & $2330(13)$ & $2286(9)$ & $131(15)$ & \\
\hline C46 & $1476(15)$ & $2019(17)$ & $2468(7)$ & 102(11) & \\
\hline C51 & $3829(9)$ & $1476(15)$ & $1345(7)$ & $61(11)$ & 0.32 \\
\hline C52 & $3502(9)$ & $562(14)$ & $894(10)$ & $83(11)$ & \\
\hline C53 & $3387(12)$ & $568(17)$ & $151(12)$ & $126(14)$ & \\
\hline C54 & $3633(13)$ & $1496(23)$ & $-166(8)$ & $132(18)$ & \\
\hline C55 & $3931(12)$ & $2437(16)$ & 256(12) & $119(14)$ & \\
\hline C56 & $4013(9)$ & 2411(12) & $1002(10)$ & $80(10)$ & \\
\hline 0 & $9328(7)$ & $1540(9)$ & $4384(5)$ & $110(7)$ & \\
\hline C6 & $10300(19)$ & $990(14)$ & $4196(10)$ & $143(14)$ & \\
\hline C7 & 9736(17) & $-37(16)$ & $3807(9)$ & 154(13) & \\
\hline C8 & 9904(24) & $2569(20)$ & 4737(17) & $210(21)$ & \\
\hline $\mathrm{Cg}$ & $8993(28)$ & $3125(19)$ & 4894(15) & $216(20)$ & \\
\hline
\end{tabular}


product was recrystallized from absolute ethanol and dried.

Cells and electrodes. The preparative reductions were performed in an $\mathrm{H}$-cell with a cathodic compartment of $150 \mathrm{ml}$. In the standard experiment a mercury pool $\left(35 \mathrm{~cm}^{2}\right)$ was used as cathode and carbon as anode. The reference electrode was a silver wire $(\mathrm{Ag} / \mathrm{AgI})$.

Instrumentation. The potentiostat and the galvanostat used in the electrolysis were both from Juul Electronic.

NMR as well as HPLC were used for determination of the cis/trans ratio of the product.

$N M R$. NMR Spectra were recorded on a Varian $300 \mathrm{MHz}$ instrument for accurate determinations, whilst for the routine analyses a Varian CFT 20 was used. The isomer ratio was found by comparing the area of twc pairs of peaks, viz. $(\delta=3.81$, $J=9.2 \mathrm{~Hz}$, trans-isomer $)$ and $(\delta=4.23, J=$ $7.0 \mathrm{~Hz}$, cis-isomer), respectively.

HPLC. The analyses were made on an Altex $110 \mathrm{~A}+420$ HPLC coupled with a UV-detector (Cecil Instrument 212). The isomers were separated on a RP-18 column $(l=30 \mathrm{~cm})$, using $60 \%$ $(v / v)$ methanol as eluent at a flow-rate of $1 \mathrm{ml}$ $\mathrm{min}^{-1}$ and monitoring (UV) at $270 \mathrm{~nm}$. The chromatograms were integrated with an HP3380 integrator.

$X$-Ray technique. Symmetry and preliminary cell dimensions were determined from films. A crystal of dimensions $0.2 \times 0.2 \times 0.3 \mathrm{~mm}$ was used for data collection on a HUBER four-circle diffractometer using $\mathrm{Cu} K \alpha$ radiation. The cell dimensions were refined using 35 reflections. Data were collected for $k$ positive out to $\theta=20^{\circ}$ with the step-scan technique ( $1 \mathrm{~s}$ per step, 50 steps in $\omega-2 \theta$ scan, scan width $0.5+0.346 \tan \theta$ in $\theta$ ). A total of 3949 reflections were measured, giving 1488 independent and 752 significant reflections $(I>3 \sigma I)$. Profile analysis was performed by the LehmannLarsen method, ${ }^{19}$ and correction for Lorentz and polarization effects were made but no absorption correction was applied. The structure was solved using the MULTAN programme system, ${ }^{20}$ but only after several renormalizations corresponding to different numbers of carbon atoms per cell. Subsequent Fourier syntheses revealed the sol- vent molecule and the hydrogen atoms. Leastsquares refinement allowing for anisotropic movement of the non-hydrogen atoms but with isotropic thermal parameters for the hydrogen atoms, which were kept at the calculated positions, gave a final $R$-value of 0.040 . The scattering curves used were those calculated by Cromer

Table 8. Distances $(\AA)$ and angles $\left(^{\circ}\right)$ in trans-2 not involving hydrogen. Standard deviations in parentheses are given in terms of the least significant digit.

\begin{tabular}{|c|c|c|c|c|c|}
\hline \multicolumn{2}{|l|}{ Distances } & \multicolumn{4}{|c|}{ Angles } \\
\hline $\mathrm{C} 1-\mathrm{C}_{2}$ & $1.534(11)$ & $\mathrm{C} 2$ & $-C_{1}$ & $-C 5$ & $102.4(8)$ \\
\hline $\mathrm{C} 2-\mathrm{C} 3$ & $1.344(10)$ & $\mathrm{C} 2$ & $-\mathrm{C} 1$ & $-C_{11}$ & 113.1(9) \\
\hline $\mathrm{C} 3-\mathrm{C} 4$ & $1.504(10)$ & $\mathrm{C} 2$ & $-\mathrm{C} 2$ & $-C_{12}$ & $108.7(8)$ \\
\hline $\mathrm{C} 4-\mathrm{C} 5$ & $1.519(10)$ & C5 & $-\mathrm{C} 1$ & $-\mathrm{C} 11$ & $110.9(9)$ \\
\hline $\mathrm{C} 1-\mathrm{C} 5$ & $1.558(10)$ & C5 & $-C_{1}$ & $-\mathrm{C} 12$ & $110.5(9)$ \\
\hline $\mathrm{C}_{1}-\mathrm{C}_{11}$ & $1.481(11)$ & C11 & $-\mathrm{C} 1$ & $-C_{12}$ & $110.9(9)$ \\
\hline $\mathrm{C} 11-\mathrm{N} 11$ & $1.104(11)$ & $\mathrm{C} 1$ & $-\mathrm{C} 2$ & $-\mathrm{C} 3$ & $108.4(9)$ \\
\hline $\mathrm{C}_{1}-\mathrm{C}_{12}$ & $1.493(11)$ & C1 & $-\mathrm{C} 2$ & $-\mathrm{C} 31$ & $120.0(9)$ \\
\hline $\mathrm{C} 12-\mathrm{N} 12$ & $1.140(10)$ & C3 & $-\mathrm{C} 2$ & $-\mathrm{C} 31$ & $131.2(9)$ \\
\hline $\mathrm{C} 2-\mathrm{N} 2$ & $1.326(10)$ & $\mathrm{C} 2$ & $-\mathrm{C} 3$ & $-C 4$ & $112.5(10)$ \\
\hline C3 -C31 & $1.429(11)$ & $\mathrm{C} 2$ & $-\mathrm{C} 3$ & $-C 31$ & $123.8(9)$ \\
\hline C31-N31 & $1.136(11)$ & $\mathrm{C} 4$ & $-\mathrm{C} 3$ & $-\mathrm{C} 31$ & $123.6(10)$ \\
\hline $\mathrm{C} 4-\mathrm{C} 41$ & $1.509(11)$ & C3 & $-C 31$ & $-N 31$ & $176.5(11)$ \\
\hline $\mathrm{C} 41-\mathrm{C} 42$ & $1.377(11)$ & C3 & $-C 4$ & $-\mathrm{C} 5$ & $103.0(9)$ \\
\hline C41-C46 & $1.356(12)$ & C3 & $-C 4$ & $-C 41$ & $117.1(9)$ \\
\hline $\mathrm{C} 42-\mathrm{C} 43$ & $1.382(13)$ & $\mathrm{C} 5$ & $-C 4$ & $-C 41$ & $115.0(10)$ \\
\hline $\mathrm{C} 43-\mathrm{C} 44$ & $1.354(16)$ & $\mathrm{C} 4$ & $-\mathrm{C5}$ & $-\mathrm{C} 1$ & $102.8(9)$ \\
\hline C44-C45 & $1.363(14)$ & $\mathrm{C}_{1}$ & $-\mathrm{C5}$ & $-C 51$ & $113.7(9)$ \\
\hline C45-C46 & $1.384(16)$ & $\mathrm{C} 4$ & $-C 5$ & $-\mathrm{C} 51$ & $119.9(10)$ \\
\hline C5 $-\mathrm{C} 51$ & $1.511(12)$ & $\mathrm{C} 1$ & $-C 11$ & $-N 11$ & $179.0(13)$ \\
\hline C51-C52 & $1.370(11)$ & $C_{1}$ & $-\mathrm{C} 12$ & $-\mathrm{N} 12$ & $175.8(12)$ \\
\hline C51-C56 & $1.366(11)$ & $\mathrm{C} 4$ & $-C 41$ & $-C 42$ & $123.1(15)$ \\
\hline C52-C53 & $1.368(14)$ & $\mathrm{C} 4$ & $-C 41$ & $-C 46$ & $120.8(14)$ \\
\hline C53-C54 & $1.356(15)$ & C42 & $-C 41$ & $-C 46$ & 116.1(12) \\
\hline C54-C55 & $1.367(14)$ & C41 & $-C 42$ & $-C 43$ & $122.6(11)$ \\
\hline C55-C56 & $1.386(14)$ & C42 & $-C 43$ & $-C 44$ & $120.6(16)$ \\
\hline $\mathrm{O}-\mathrm{C} 6$ & $1.389(14)$ & C43 & $-C 44$ & $-\mathrm{C} 45$ & $117.4(19)$ \\
\hline C6 - C7 & $1.463(14)$ & C44 & $-C 45$ & $-C 46$ & $122.0(17)$ \\
\hline $\mathrm{O}-\mathrm{C} 8$ & $1.447(18)$ & C45 & ;-C46 & $-\mathrm{C} 41$ & $121.3(15)$ \\
\hline $\mathrm{C} 8-\mathrm{C} 9$ & $1.308(18)$ & C5 & $-C 51$ & $-C 52$ & $123.5(15)$ \\
\hline & & C5 & -C51 & $-C 56$ & $120.8(15)$ \\
\hline & & C52 & $-\mathrm{C} 51$ & $-\mathrm{C} 56$ & $115.5(11)$ \\
\hline & & C51 & $-\mathrm{C} 52$ & $-C 53$ & $122.9(13)$ \\
\hline & & C52 & $-\mathrm{C} 53$ & $-C 54$ & $120.4(17)$ \\
\hline & & C53 & - C54 & $-C 55$ & $118.9(17)$ \\
\hline & & C54 & $-C 55$ & $-C 56$ & $119.4(15)$ \\
\hline & & C55 & $-C 56$ & $-C 51$ & $122.8(11)$ \\
\hline & & C6 & -0 & $-\mathrm{C} 8$ & $108.3(14)$ \\
\hline & & 0 & $-\mathrm{C} 6$ & $-C 7$ & $110.0(16)$ \\
\hline & & 0 & $-\mathrm{C} 8$ & $-\mathrm{C} 9$ & $109.7(23)$ \\
\hline
\end{tabular}


and $\operatorname{Mann}^{21}(\mathrm{C}, \mathrm{N}, \mathrm{O})$ and Stewart, Davidson and Simpson $^{22}(\mathrm{H})$. The weighting scheme was $w=$ $\left\{\sqrt{ }\left[\sigma_{c}\left(F^{2}\right)+1.03 F^{2}\right]-F\right\}^{-1}$, the refinement on $F$. Coordinates for the non-hydrogen atoms are given in Table 7 together with the distance of these atoms from the best plane through the central 5-ring. Table 8 lists distances and angles not involving hydrogen atoms. Lists of thermal parameters, hydrogen atoms and of observed and calculated structure factors can be obtained from one of the authors (RGH) on request.

Acknowledgement. We thank Dr. Ole Hammerich, University of Copenhagen, for valuable discussions and for the use of his electroanalytical equipment.

\section{References}

1. Baizer, M. M. In: Baizer, M. M. and Lund, H., Eds., Organic Electrochemistry, 2nd ed., Marcel Dekker, New York 1983.

2. Lamy, E., Nadjo, L. and Savéant, J. M. J. Electroanal. Chem. 42 (1973) 189.

3. Nadjo, L., Savéant, J. M. and Tessier, D. J. Electroanal. Chem. 64 (1975) 143.

4. Nadjo, L. and Savéant, J. M. J. Electroanal. Chem. 73 (1976) 163.

5. Avaca, L. A. and Utley, J. H. P. J. Chem. Soc., Perkin Trans. I (1975) 971.

6. Avaca, L. A. and Utley, J. P. H. J. Chem. Soc., Perkin Trans. 2 (1975) 161.

7. Delaunay, J., Lebouc, A., Le Guillanton, G., Mavoungou Gomes, L. and Simonet, J. Electrochim. Acta 27 (1982) 287.
8. Lerflaten, O. and Parker, V.D. Acta Chem. Scand., Ser. B 36 (1982) 225.

9. Abou-Elenien, G., Beucher, B., Ismail, N., Rieser, J. and Wallenfels, K. Z. Naturforsch. Teil B38 (1983) 1199.

10. Andrieux, C. P., Nadjo, L. and Savéant, J. M. J. Electroanal. Chem. 26 (1970) 147.

11. Ahlberg, E. and Parker, V.D. J. Electroanal. Chem. 121 (1981) 73.

12. Ahlberg, E. and Parker, V. D. Acta Chem. Scand., Ser. B35 (1981) 117.

13. Matthews, W.S., Bares, J.E., Bartmess, J.E., Bordwell, F. G., Cornforth, F. J., Drucker, G. E., Margolin, Z., McCallum, R.J., McCallum, G.J. and Vanier, N. R. J. Am. Chem. Soc. 97 (1975) 7006.

14. Kolthoff, I. M., Chantooni, M. K. and Bhowmik, S. J. Am. Chem. Soc. 90 (1968) 23.

15. Caldin, E. F. Fast Reactions in Solution, Blackwell, Oxford 1964.

16. Petrovich, J. P. and Baizer, M. M. J. Electrochem. Soc. 118 (1971) 447.

17. Corson, B. B. and Stoughton, R. W. J. Am. Chem. Soc. 50 (1928) 2825.

18. Nielsen, M. F., Hammerich, O. and Parker, V. D. Acta Chem. Scand., Ser. B 40 (1986) 101.

19. Lehmann, M.S. and Larsen, F. K. Acta Crystallogr., Sect. A 30 (1974) 580.

20. Germain, G., Main, P. and Woolfson, M. M. Acta Crystallogr., Sect. A 27 (1971) 368.

21. Cromer, D. T. and Mann, J. B. Acta Crystallogr., Sect. A 24 (1968) 321.

22. Stewart, R.F., Davidson, E. R. and Simpson, W. T. J. Chem. Phys. 42 (1965) 3175.

Received November 19, 1986. 